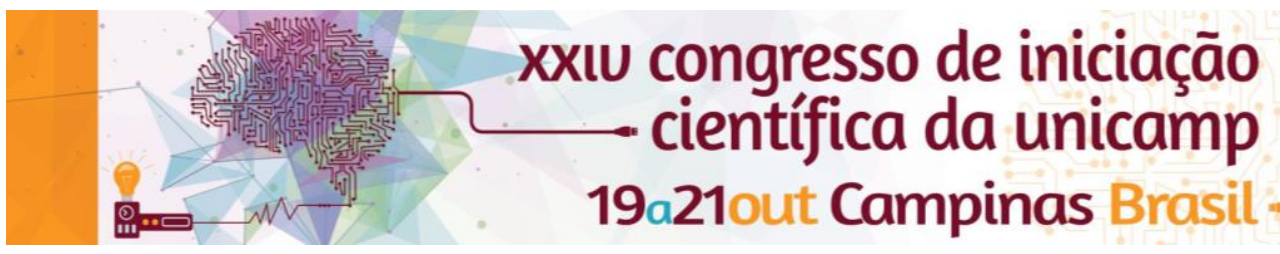

\title{
Medidas Online de Densidade como Forma de Monitorar a Síntese de Biodiesel
}

\author{
Arnaldo G. de Oliveira Jr.*, Matthieu Tubino.
}

\section{Resumo}

Medidas de densidade da mistura reacional durante a síntese do biodiesel foram utilizadas para obter informações sobre a cinética da reação de transesterificação.

\section{Palavras-chave}

Síntese de biodiesel, densidade, monitoramento online.

\section{Introdução}

A reação de transesterificação de triacilgrlicerídeos com álcool que ocorre na síntese do biodiesel provoca mudanças em propriedades físicas da mistura reacional por exemplo: no índice de refração, na viscosidade, na densidade. Através de medições contínuas da densidade, ou da massa de um volume fixo da mistura reacional, é possível monitorar o andamento da reação, podendo-se, portanto, avaliar a composição da mistura reacional e, consequentemente, verificar a formação dos metil-ésteres. Nesse contexto, foi construído, em nosso laboratório, um sistema para determinar continuamente a densidade da mistura reacional contendo óleo de soja, metanol e metóxido de sódio como catalisador.

\section{Resultados e Discussão}

A mistura reacional, composta por $700,0 \mathrm{~g}$ de óleo de soja comercial, $120,0 \mathrm{~g}$ de metanol e $3,4 \mathrm{~g}$ de uma solução de metóxido de sódio a $30 \% \mathrm{~m} / \mathrm{m}$ em metanol, foi mantida sob agitação mecânica $(620 \mathrm{rpm})$ na temperatura ambiente $\left(27^{\circ} \mathrm{C}\right)$, em um balão de fundo redondo. A amostragem foi feita continuamente por sucção usando uma bomba peristáltica. A amostra é conduzida através de uma rede de tubos de polietileno passando por uma espiral de volume fixo colocada no prato de uma balança analítica. Nessa rede há dois separadores de bolhas de ar e da fração menos densa insolúvel na matéria gordurosa.

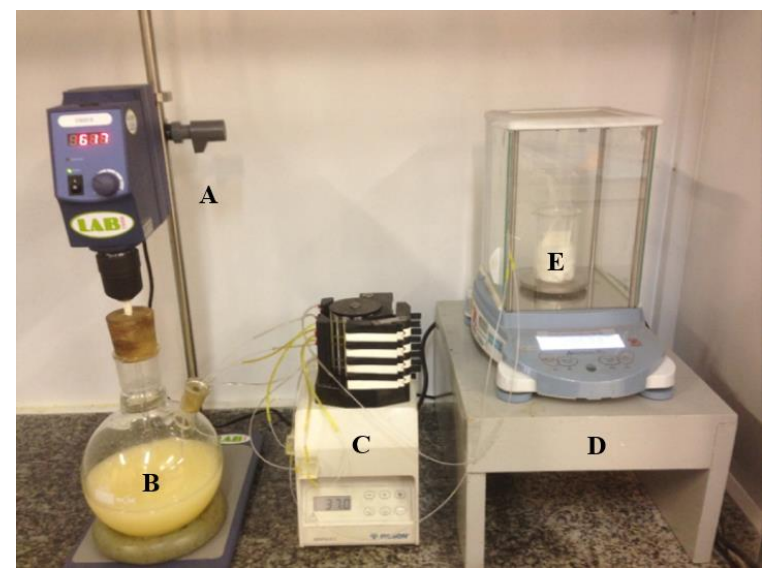

Figura 1. Equipamento utilizado para as medidas de densidade da mistura reacional: A) Agitador mecânico; B) Frasco reacional; C) Bomba peristáltica; D) Balança analítica; E) Espiral de polietileno, de volume fixo.

As medidas de massa (e consequentemente densidade) foram obtidas a cada trinta segundos com 0 auxílio de software. Os dados foram utilizados para construir uma curva correlacionando a massa do sistema com o tempo de reação. Conforme esperado, pela diferença na densidade dos reagentes e produtos, aparecem mudanças no perfil da curva em consequência da variação de massa contida na espiral. Surgem claramente três diferentes etapas ao longo da reação de transesterificação: 1) a dispersão do metanol em óleo, causando redução na massa da mistura contida no interior da espiral devido à menor densidade do metanol, seguido de estabilização; 2) a adição do catalisador (metóxido de sódio), que causa decréscimo na massa do sistema por causa da conversão do óleo em biodiesel; 3) estabilização final, que indica o fim da reação.

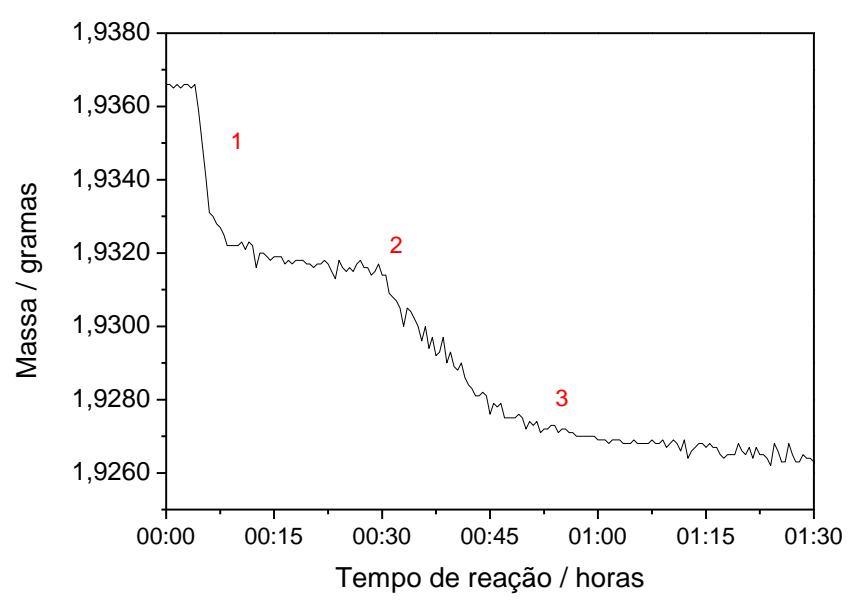

Figura 2. Perfil de variação de massa obtido através das medidas online de massa em função do tempo de reação.

\section{Conclusões}

O sistema proposto e testado neste trabalho permite o acompanhamento "on line" da reação de transesterificação através de medidas de massa (densidade) da mistura reacional. Este tipo de informação permite melhor visualizar a reação, com o que é possível propor ajustes reacionais com o intuito de otimizar o processo de produção de biodiesel.

\section{Agradecimentos}

Ao SAE, pela Bolsa BAS

Ao CNPq, pelo financiamento do projeto.

$\overline{1}$ Rocha Junior, J. G.; Bauerfeldt, G. F. e Tubino, M. Fuel. 2014, 125, 164.

${ }^{2}$ Lôbo, I. P.; Ferreira, S. L. C. Química Nova. 2009, 32, 1596. 